\title{
PO PRÁCI HLADOVÍ, NA VLASTNÍCH SLOVECH SI POCHUTNÁVÁME ANEB STRÁVNÍK JIŘí WOLKER
}

\author{
TEREZA KOPECKÁ - ZUZANA SCHIEROVÁ - \\ RENATA FERKLOVÁ - ALEŠ MISA ̌̌
}

\section{‘HUNGRY FROM WORK, WE DELIGHT IN OUR OWN WORDS’ OR JIŘí WOLKER EATING}

The collection of photographs of the National Museum of Education and Jan Amos Comenius Library contains a file related to the Student Home institution in the 1920s. One of those photographs by coincidence shows the poet Jiří Wolker at the table in the students' canteen. The aim of those contributions is to publish this photograph, date it with more precision, to prove, with the aid of further sources, that the poet used to eat at this canteen during this part of his life, and to identify the other persons sitting at his table.

Keywords: Jiř́ Wolker - photography - Albertov - student canteen

DOI: $10.14712 / 23365730.2021 .4$

\section{Úvod}

Najít dosud neznámý pramen $\mathrm{k}$ intenzivně probádanému tématu je př́ležitost, která se historikovi naskytne zrrídkakdy. Ale spolehlivě identifikovat na fotografii básníka, který zemřel ve dvacátých letech 20. století, je obtížné. Pamětníci už nežijí, a tak se musíme spoléhat na metody antropologické a na doložení skutečného výskytu dané osoby v daném místě a čase. O to větší radost je, když všemi metodami dojdeme ke konsenzu a můžeme prakticky s jistotou říct, že máme před sebou dosud neznámou fotografii Jiř́iho Wolkera.

\section{Metody a prameny}

Na počátku této práce byla dizertace $\mathrm{z}$ dějin lékařství, pro kterou bylo nutné získat fotografie pražských vysokoškolských studentů z 20. let 20. století. Mezi fotografiemi, které poskytlo Národní pedagogické muzeum v Praze, bylo i několik snímků ze Studentského domova na pražském Albertově. Při bližším studiu nebylo možné na fotografii ${ }^{1} \mathrm{z}$ menzy přehlédnout osobu, která velmi připomínala Jiřího Wolkera. V této práci jsme se zaměřili na otázky, zda to byl skutečně on, kdo s ním sedí u stolu a kdy byla fotografie pořízena.

1 Sbírková fotografie číslo F 0323_6. Fotografie pochází ze sbírky Národního pedagogického muzea a knihovny J. A. Komenského. Autor digitálních kopií: Petr Šolar. 
K identifikaci osob jsme v první řadě použili postupy subjektivní - vizuální porovnání hodnocených fotografií ve srovnání s ověřenými fotografiemi daných osob. Referenční snímky jsme našli v různých pramenech - archivech, ${ }^{2}$ publikovaných pramenech, ${ }^{3}$ memoárech ${ }^{4}$ databázích odborných společnostî ${ }^{5}$ a na webových stránkách. ${ }^{6}$ Tyto fotografie jsme pak využili i k porovnání pomocí objektivních metod. $V$ těch jsme se soustředili na tvarovou podobnost jednotlivých rysů, a to jednak vizuálně, jednak jsme provedli analýzu pomocí aplikace IAT (Image Analysis Toolset). ${ }^{7} \mathrm{~K}$ přibližné dataci nám pomohly zejména korespondence a memoáry, při jejichž zpracovávání jsme měli na paměti jejich věcné limity. ${ }^{8}$

\section{Studentský domov a Wolker?}

Instituce, která je dnes známa nejspíše pod názvem albertovská menza nebo Menza Albertov a která díky své lokalizaci hostí studenty různých fakult Univerzity Karlovy i ČVUT, se v době svého vzniku a ještě dlouho poté jmenovala Studentský domov. V letech 1920/1921 ji postavila americká společnost YMCA (Křest’anské sdružení mladých lidí) „z peněz, jež pro pražské studentstvo sebrala univerzita a občanstvo v Ohiu“. Studenti zde měli možnost levně bydlet, stravovat se, studovat a trávit volný čas. Studentský domov zároveň představoval pro studenty možnost zaměstnání. Svoji činnost zahájil na konci února 1921. ${ }^{9}$ Účelný systém samoobsluhy umožnil stravování až 2000 studentů denně. ${ }^{10}$

Je racionální hledat v menze Jiř́ho Wolkera? Po maturitě v roce 1919 se zapsal na Právnickou fakultu Univerzity Karlovy, ale k tomu, aby mohl získat legitimaci na nákup poukázek ke stravování v menzách, bylo nutné vysvědčení nemajetnosti, a to neměl, což dokládá fakt, že jeho žádost o osvobození od kolejného nebyla kladně vyř́zena: „Platím prý př́liš vysokou dan̆ z př́jmu (387 K), a proto osvobozen nejsem." ${ }^{11}$ Jak by se tedy do menzy dostal?

Odpověd' nacházíme v knize autorů Hlinky a Všetečky, kde je citován dopis Wolkerova spolužáka z gymnázia i z právnické fakulty Jana Pospíšila: „Jednu dobu jsem byl zaměstnán jako tajemník ve Studentském domově v Praze-Nuslích Na Slupi. Tam prišel za mnou Jirka ještě s jiným mužem (prý členem Devětsilu) a stěžoval si mi, že se ho rodina žrekla pro jeho

2 Literární archiv Památníku národního písemnictví, fond Kalista Zdeněk, fotografie, vlastní, album; tamtéž, fond Konrád Karel, fotografie.

3 Bohuslav HlinKa - Jiří VŠETEČKa, Den se mi v rukou přelomil, Praha 1990.

4 Zdeněk Kalista, Po proudu života, I, Brno 1997; TÝž, Tvář́e ve stínu, Praha 2017; Pavel Marek, Katalog výstavy o životé a dile JUDr I. Sekaniny (1900-1940), Prostějov, 1984.

5 Historický ústav AVČR, Bibliografie dějin českých zemí: <https://biblio.hiu.cas.cz/authorities/7395> (Citováno 15. 3. 2020]; <https://www.medvik.cz/bmc/link.do?id=jk01060315> (Citováno 15. 3. 2020).

$6<$ https://prostor-ad.cz/pruvodce/praha/sporilov/spisovat/kalista.htm> (Citováno 15. 3. 2020); <https://cs .wikipedia.org/wiki/Zden\%C4\%9Bk_Kalista> (Citováno 15. 3. 2020); <http://encyklopedie.idu.cz/index .php/P\%C3\%AD\%C5\%A1a,_Anton\%C3\%ADn_Mat\%C4\%9Bj> (Citováno 13. 10. 2020); <http://www .slovnikceskeliteratury.cz/showContent.jsp?docId=541> (Citováno 13. 10. 2020); <https://www.ceskatelevize .cz/porady/10123383458-pribehy-slavnych/403235100101006-jedna-basen/> (Citováno 14. 10. 2020).

$7<$ https://play.google.com/store/apps/details?id=tk.silviomarano.imageanalysistoolset\&hl=en_US> (Citováno 15. 3. 2020).

8 Milada SeкYrková (ed.), Paměti a vzpomínky jako historický pramen, Praha 2006.

9 Otevreni studentského domova, Čas 31/49 (27.02. 1921), s. 8.

10 Český svět 17/32 (28. 4. 1921), nestránkováno.

11 Jiř́i Wolker, Dopisy, Praha 1984, otci, č. 46, 5. 11. 1919, s. 50. - „A to vysvědčení nemajetnosti Ti tata vystavit nemůže, poněvadž by mu je na žádném úŕadě nepotvrdili.“ Wolkerová Zdena Wolkerovi Jiřímu, dopis č. 51, 25. 10. 1920, s. 61. 
vstup do Devětsilu a že je na tom bídně. Sám jsem mu tehdy maličkostí (poukázky na oběd) vypomohl."12

Přestože se Wolker svým rodičům o stravování v menze nezmiňuje, o jeho návštěvě na Albertově jsme v korespondenci s přáteli našli ještě jeden doklad. V lednu roku 1922 napsal príteli Konstantinu Bieblovi z Prostějova stručný dopis: „,Milý Kosto, přijedu v pondělí 23. t. m. odpoledne v 15,30 (Wilsonovo). Nepřijdeš-li na dráhu, přijdi určitě ke mně. Chtěl bych s Tebou strávit první večer, nebot mnoho si máme co ř́ci. Těším se už nesmírně, nebot jsem se zdržel doma déle, než bylo záhodno. Ostatni ústně. Tvịj Jiři Wolker. P.S. Mohl bys mi snad opatřit na ponděli listek na večeři do Domova?"13

Mohl to být tedy i medik Konstantin Biebl, kdo Wolkerovi poukázky obstaral. Na Lékařskou fakultu Univerzity Karlovy nastoupil na podzim roku $1920^{14}$ a po celý zbytek Wolkerova života zde studoval ${ }^{15}$ (přinejmenším byl studentem LF UK, at' bylo jeho momentální studijní úsilí jakékoli $\left.{ }^{16}\right)$. Vzhledem $\mathrm{k}$ jeho rodinným a sociálním poměrům se domníváme, že on vysvědčení nemajetnosti mohl mít, a mohl tedy Wolkerovi poskytnout svoje menzovní poukázky.

\section{Datace}

Datace snímku byla jedním z našich hlavních cílů a $\mathrm{k}$ jeho dosažení nám pomohla $\mathrm{v}$ první řadě fotografie sama. Prohlédneme-li si ji pečlivě, vidíme, že věšáky jsou plné teplých kabátů a klobouků či čepic, dámy a dívky mají na hlavách teplé klobouky, dívka v popředí má teplý kabát přehozený přes volnou židli. Máme tedy jistotu, že byla pořízena $\mathrm{v}$ chladném období roku, tedy někdy mezi pozdním podzimem a časným jarem. Stropní světla nesvítí, znamená to tedy, že se jedná o oběd, protože $\mathrm{v}$ zimě by se večeře pravděpodobně neodbývala za denního světla.

Dalším pomocníkem je korespondence, ve které bylo nutno zjistit, kdy měl Wolker výpadek stravování.

Svůj první pražský rok strávil v rodině svého kamaráda ze skautu a spolužáka z právnického studia Přemysla Borůvky, kde byl přijat na byt a stravu. ${ }^{17}$ Nebyl tam ale př́liš spokojený, zejména $\mathrm{v}$ době, kdy rodinu sužovala španělská chřipka. ${ }^{18}$ Jídlo tu prý navíc bývalo hladové. ${ }^{19}$

Druhý rok svých studií (1920-1921) strávil na Smíchově v ulici Na Celné u Čapků, kde bydlel se svým starším kolegou z Prostějova Jiřím (později Kaprálkem) Škrachem a bydlení bylo taktéž se stravou. ${ }^{20}$ Jídlo bylo zřejmě opět hladové. ${ }^{21}$ Naskytla se ale

12 B. HlinKa - J. VŠEtečKa, Den se mi v rukou přelomil, s. 216.

13 J. Wolker, Dopisy, Bieblovi Konstantinu, č. 282, 20. 1. 1922, s. 300.

14 Archiv Univerzity Karlovy, Fond Lékařská fakulta, Katalog studentů Medikové řádní a mimořádní, díl R-Ž a mimořádní.

15 Archiv Univerzity Karlovy, Fond Lékařská fakulta, Personálie studentů - neúspěšné studium, složka Konstantin Biebl.

16 Konstantin Biebl - Zdena WolkerovÁ - Jan KüHndel - Jiří Wolker, Listy dvou básníki̊, Praha 1953 , s. 34.

17 J. Wolker, Dopisy, Jiř́ Wolker matce, dopis č. 39, 3. 10. 1919, s. 40.

18 Tamtéž, matce, č. 52, 28. 1. 1920, s. 57.

19 Tamtéž, otci, č. 58, 29. 2. 1920, s. 63-64.

20 Tamtéž, matce, č. 61, 10. 10. 1920, s. 67.

21 Tamtéž, matce, č. 63, 30. 10. 1920, s. 71, rodičům, č. 62, 19. 10. 1920, s. 69. 
jiná možnost obědů - u obchodního př́itele Ferdinanda Wolkera, pana Krause. ${ }^{22}$ Kvalita i množství jídla u Čapků byly stále horší a horší a po jednom velmi špatném obědě ztropil kolega Škrach povyk a ubytování opustil. ${ }^{23}$ Ani Wolker už tu nebyl spokojen a návrat do Prostějova ohlašoval ihned po skončení přednášek na 5 . prosince. ${ }^{24}$ Po návratu $\mathrm{z}$ vánočních prázdnin v lednu roku 1921 s paní bytnou domluvil jen snídaně a svačiny za 30 Kč a zřejmě měsíčně nějakou mouku, ${ }^{25}$ na obědy chodil ke Krausům. ${ }^{26}$ Večeře si obstarával sám, tatínkovi je účtoval po pěti korunách, dostával na ně pomoc v balíčcích z domova. ${ }^{27}$ Termín na státnici dostal 9. března 1921 dopoledne. ${ }^{28}$ Hned po ní se chystal vrátit domů. ${ }^{29}$ Do Prahy pak znovu přijel až v květnu, kdy už bylo teplo. Jeho spolubydlícím se mezitím stal Zdeněk Kalista.

Svůj př́ijezd k zápisu do třetího ročníku, a tedy akademického roku 1921/1922, ohlásil Wolker příteli Kalistovi na odpoledne 14. ř́ina a žádal ho, aby mu přišel naproti na Wilsonovo nádraží a vzal s sebou klíč od domu. ${ }^{30}$ První měsíc v Praze byl Wolker nemocný. Stravoval se asi u Čapků: „Paní Čapková, - musím říci - se o mě velmi poctivě stará. Vař́ mi zvláštni jidla stravitelnějši a lehčí." ${ }^{11} \mathrm{Na}$ druhou stranu obědy tatínkovi účtuje zvlášt', nebyly snad součástí dohody o ubytování. Jeho zdravotní stav se po několika týdnech zlepšil ${ }^{32}$ a Wolker zůstal v Praze až do prosince. Posledního listopadu ohlásil rodičům svůj návrat na 5. 12. 1921 večer."33

Krize v zajišt'ování pobytu v Praze přišla nečekaně na začátku roku 1922. Paní Čapkovou ranila mrtvice, v Praze byla jen „slečna“, která na péči o domácnost nestačila. Wolker se $\mathrm{v}$ té době stravoval po hospodách. ${ }^{34}$ Naděje na obědy u Krausů nebyla, pozvali ho sice na neděle, ale nemohli vyhovět jeho finančním možnostem pro každodenní obědy. ${ }^{35} \mathrm{~V}$ únoru pak dostali Wolker s Kalistou z podnájmu v ulici Na Celné výpověd’. ${ }^{36}$

Wolker a Kalista si zaslouží krátké zastavení. Začínali v Praze jako velcí přátelé. Setkali se už roku 1919 při přípravách nového literárního časopisu Orfeus. Teprve soužití ve zmíněném podnájmu Na Celné v letech 1920-1921 je sbližilo, kráčeli spolu po cestě životní i tvůrčí. Společně chtěli dobývat literární mety a společně také chystali vydání knižní prvotiny. Ale právě to už o Velikonocích 1921 přineslo první trhliny. Wolkerova čítankově proslulá báseň Svatý Kopeček údajně využila tvưrčích postupů ze vznikající básně Růženec, kterou Kalista Wolkerovi ukázal. Aby nevzbudil dojem plagiátu, Kalista svou poemu po incidentu nikdy nedokončil. Vkradla se mezi ně nedůvěra a vzájemná obezřetnost. ${ }^{37}$ $\mathrm{K}$ tomu se přidala i žárlivost na další prátele, kteří se $\mathrm{v}$ jejich okolí objevili, např. A. M.

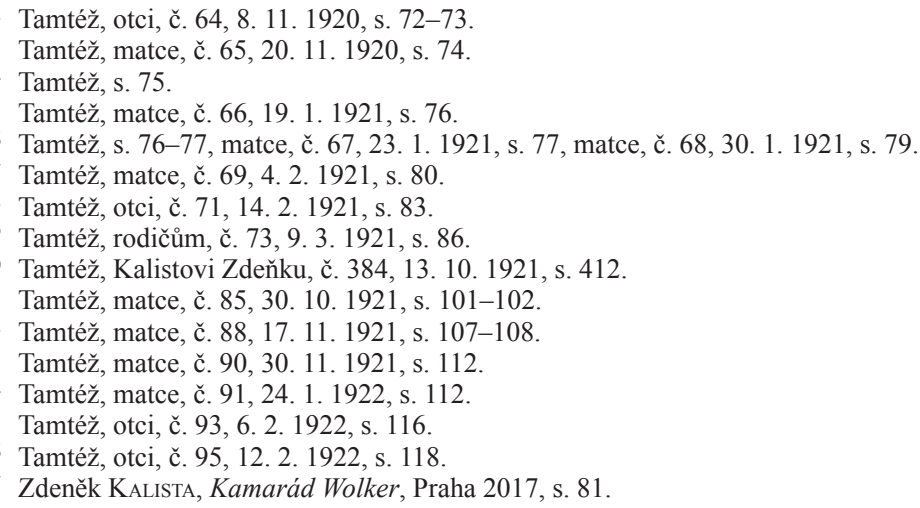


Píšu.$^{38}$ Odcizování se dovršilo i v ideové rovině, když se Wolker spolupodílel na formulování principů proletářského umění a přiklonil se $\mathrm{k}$ Devětsilu, zatímco Kalista zůstal věrný brněnské Literární skupině. Odchod z podnájmu $\mathrm{Na}$ Celné v únoru 1922 definitivně zakončil kapitolu přátelství „na život a na smrt“.

Od 1. března si našel Wolker nové bydlení v Černé ulici u paní Teigeové, matky Karla Teigeho. ${ }^{39} \mathrm{Od} 15$. března do 1 . května hodlal být doma v Prostějově, kde chtěl začít studovat na druhou státnici. Už 5. května potom píše rodičům ze Záhřebu, kde byl s Konstantinem Bieblem na cestě do Bašky.

V posledním roce svého studia nestrávil Wolker v Praze mnoho času. Bieblovi hlásil, že do Prahy přijede v neděli 1 . ř́ijna 1922 kolem půl čtvrté na Masarykovo nádražíi. ${ }^{40}$ Podobně hlásil svůj př́jezd i Teigemu. ${ }^{41}$ Nehodlal se zdržet dlouho, ale musel jít k zápisu na právnickou fakultu (k tomu byl povolán na 11. ř́ijna) a chtěl vyř́idit své literární záležitosti. ${ }^{42} \mathrm{~V}$ té době zřejmě v menze obědvat nepotřeboval, rodičům si nijak nestěžoval: „Jinak se mám dosti dobře. Maje dost peněz dobře jím, a to je hlavní."43 Domů se vracel ve středu 1. listopadu, ${ }^{44}$ ale v Černé ulici si nechával peřiny, s paní Teigeovou si dohodl možnost dalších přespání v př́ípadě vyřrizování studijních záležitostí..$^{45}$

Do Prahy se nakrátko vrátil ještě v prosinci 1922, na večer Proletkultu. Představení se konalo v Tylově divadle v Nuslích 11. prosince. ${ }^{46} \mathrm{~V}$ režii Jindřicha Honzla předvedl Dědrasbor scénické provedení Balady o snu a Wolkerovu jednoaktovku Nejvyšší obět'. Jiří Wolker chtěl být prrítomen zkouškám, proto přijel do Prahy o týden dřive. Vrátil se do Černé ulice $\mathrm{k}$ Teigeovým, ale nestravoval se zde. V den představení přijela do Prahy i paní Zdena Wolkerová, seděla $\mathrm{v}$ lóži s úspěšným autorem, byla po představení i na malé oslavě v bytě Marie Majerové. Do Prostějova se pak vraceli spolu. ${ }^{47}$ Byla to Wolkerova poslední návštěva Prahy.

O podrobnostech pobytu Jiř́ho Wolkera $\mathrm{v}$ tomto prosincovém týdnu nemáme mnoho zpráv, nemůžeme tedy vyloučit, že právě v této době našel útočiště v menze Studentského domova. $\mathrm{Z}$ divadla $\mathrm{v}$ Nuslích to neměl daleko, bylo by to praktické řešení.

\section{Devětsil}

Měla ale opravdu Wolkerova přitomnost $\mathrm{v}$ albertovské menze co do činění s Devětsilem? Vstoupil do něj na konci března $1922 .{ }^{48}$ Vývoj událostí by ale nemohl do konce zimy stihnout, přestože zima let 1921-1922 byla dlouhá a chladná. ${ }^{49}$ Oběd ve Studentském domově

38 Tamtéž, s. 91.

39 J. Wolker, Dopisy, matce, č. 96, 18. 2. 1922, s. 119-120.

40 Tamtéž, Bieblovi Konstantinu, č. 288, 27. 9. 1922, s. 307.

41 Tamtéž, Teigemu Karlu, č. 549, 27. 9. 1922 a č. 550, 28. 9. 1922, s. 585.

42 Tamtéž, matce, č. 107, 4. 10. 1922, s. 131-132.

43 Tamtéž, s. 134.

44 Tamtéž, matce, č. 111, 31. 10. 1922, s. 136.

45 Tamtéž, rodičům, č. 110, 22. 10. 1922, s. 134.

46 Zdena Wolkerová, Jiři Wolker ve vzpomínkách své matky, Praha 1937, s. 191.

47 Tamtéž, s. 191-196.

48 J. Wolker, Dopisy, Teigemu Karlu, č. 542, 29. 3. 1922, s. 579; Píšovi A. M., č. 462, 14. 12. 1921, s. $487-488$.

49 Tamtéž, Bieblovi Konstantinu, č. č. 283, konec března 1922, s. 300-301. 
by se tak jako tak musel odehrát ještě před vstupem do Devětsilu. V době oficiálního oznámení o vstupu už byl v Prostějově a na podzim 1922 měl stravování opět zajištěno.

Stejně tak není pravda, že se rodina Wolkera pro Devětsil zřekla. Představa, že by jeho vstup do tohoto uměleckého sdružení rodinu vůbec pohoršil, je absurdní. Jiří se rodičům svými literárními úspěchy v levicovém tisku chlubil, stejně jako svými prátelskými styky s levicovými intelektuály. Zvláště maminka byla na literární úspěchy svého syna pyšná a v jeho tvorbě i politické orientaci ho podporovala. ${ }^{50}$ Ve shodě s tím formulovala i své vzpomínky publikované ve 30 . letech, kdy (na rozdíl od vydání v 50. letech) neměla důvod svůj postoj k synovu „bolševictví“ přikrašlovat.

Víme také zcela jistě, že ho rodiče na studiích finančně podporovali, byt' rozpočet jeho potřeb byl veden dosti př́sně. Pokud tedy Wolker potřeboval menzovní obědy, bylo to spíše z nedostatku jiných příležitostí, jak si stravování zajistit, případně z důvodu momentální finanční tísně (pokud např́íklad peníze určené na obědy použil na jiný účel).

Z toho vyplývá, že chceme-li Wolkerovu fotografii v menze Studentského domova Na Slupi datovat, nejpravděpodobnější je začátek roku 1922, kdy nemoc bytné paní Čapkové přinesla velké problémy v zajišt’ování obědů. Nemůžeme vyloučit ani prosincový týden 1922, kdy se autor účastnil zkoušek na představení Proletkultu, stravování neměl zajištěno a albertovská menza se blízkostí od Tylova divadla v Nuslích př́mo nabízela. Bieblova korespondence a Pospíšilova zpráva o poukázkách do menzy sice verifikují Wolkerovu prítomnost na Albertově, ale dataci nám neodhalily.

\section{Analýza fotografie}

Fotografie zachycuje interiér jídelny Studentského domova, v níž sedí u stolů studenti (a pravděpodobně i jejich učitelé) ${ }^{51}$ a obědvají. Právě jejich spontánní chování v době oběda situaci poněkud znesnadňuje, protože nejsou v pozicích, které bychom z hlediska studia jejich skeletu zvláště ocenili. Navíc má většina z nich plná ústa a Jiří Wolker má zavřené oči.

Wolker sedí zcela vlevo a u jeho stolu můžeme vidět ještě dva další muže. Muže v pozadí jsme bez obtíží a v naprosté shodě identifikovali jako pozdějš́ího profesora gynekologie a porodnictví (také ředitele Všeobecné nemocnice a předsedu České gynekologické a porodnické společnosti) Karla Klause. ${ }^{52}$ Identifikovali jsme ho na základě srovnání s fotografí́ z pozůstalosti doc. Václava Šebka, která je deponována v archivu Národního muzea $^{53}$ (a na které je společně s docentem Šebkem a profesorem Peterem). Nález jsme ještě konfrontovali s pozdější fotografií, která je dostupná např́iklad na Bibliografii dějin českých zemí (Historický ústav AV ČR). ${ }^{54}$

K identifikaci Jiř́iho Wolkera jsme použili jako referenční snímek jeho fotografie z období kolem maturity, na kterých je podobně starý a v podobném stavu výživy. Nutriční stav

50 Jiří WoLKER, Korespondence s rodiči, Praha 1952, dopis z 25. 10. 1920, s. 60-61, pohlednice z 16. 10. 1922, s. 118; Z. WOLKEROVÁ, Jiři Wolker ve vzpomínkách své matky, s. 169; Edvard VALENTA, Život samé psaní, Praha 1970, s. 79.

51 Tyfová otrava, Večer: lidový deník 9, č. 168 (27. 7. 1922), s. 3.

$52<$ https://www.medvik.cz/bmc/link.do?id=jk01060315> (Citováno 15. 3. 2020).

53 Archiv Národního muzea, fond Šebek Václav, datace: 1931-1978.

54 Historický ústav AVČR, Bibliografie dějin českých zemí: <https://biblio.hiu.cas.cz/authorities/7395> (Citováno 15.3.2020). 
se u něj jako u mnoha nemocných s pokročilou/terminální tuberkulózou výrazně měnil. Plnější nebo hubenější tváře pak mohou vytvářet jiný obrys obličeje, aktuální objem corpus adiposum buccae také ovlivňuje posazení ušních boltců, ačkoli pozice tragu se nemění. V závislosti na podkožním tuku se může měnit i tvar rtů a množství tukové tkáně v orbitě může mít za následek změnu výrazu očí. Není tedy možné použít náhodnou fotografii výběr je nutné důkladně zvážit.

Podíváme-li se na Wolkerovu podobu na fotografii z menzy systematicky, vidíme, že tvar brady přesně odpovídá referenční fotografii, stejně tak i tvar uší a úhel mandibuly. Tvar a plnost rtů jsou rovněž totožné, i tvar nosu. Oči jsou zavřené, ale nelze na nich diferencovat rysy, které by se od srovnávací fotografie odlišovaly. Nadočnicové oblouky a tvar obočí jsou totožné, zcela charakteristické. Celkový výraz tváře je nápadně wolkerovský.

Jedinou spornou položkou je frontální vlasová hranice. Jiří Wolker měl na různých fotkách různé účesy, většinou krátké až polodlouhé vlasy česané dozadu a doprava. Na referenčních fotografích vybíhala v mediánní čáře frontální vlasová hranice kaudálně, ale tento výběžek se zdá být na fotografii z menzy poněkud užší než na ostatních fotografiích. Tato drobná odlišnost může být ovšem způsobena tím, že se Wolker v přeplněné jídelně zpotil a krátké vlasy - „,chmýří'“, které tvořily širší základnu tohoto výběžku, splynuly s ostatními vlasy. Fotografie mohla být také retušována. Tuto odlišnost tedy nepovažujeme za zásadní.

Naopak zásadní problémy jsme měli při snaze o identifikaci mladého muže, který sedí $\mathrm{v}$ popředí a poněkud rozezleně se ohlíži na fotografa. Patří vủbec $\mathrm{k}$ Wolkerovi, nebo ne? Pomysleli jsme na obě varianty, ale Wolkerova uvolněná poloha a fakt, že je na snímku již po obědě, má prázdný talíř, složený příbor, a přesto neodchází, nás vedly $\mathrm{k}$ domněnce, že na někoho čeká. Přičemž je nepravděpodobné, že by to byl Karel Klaus.

Prošli jsme desítky Wolkerových př́tel a našli jsme několik osob, jejichž př́tomnost by byla možná. Jedním z hlavních kandidátů byl Zdeněk Kalista. Faktorů, které by z hlediska antropologického svědčily pro tuto možnost, byla řada: především tvar uší a nosu, nadočnicových oblouků a frontální vlasové linie. O jeho identitě jsme byli na základě srovnání $\mathrm{s}$ veřejně dostupnými snímky přesvědčeni, ale $\mathrm{v}$ archivu Památníku národního písemnictví jsme našli řadu fotografí, které tuto domněnku vyvrátily. Po jejich prostudování jsme zjistili, že skutečný Kalista měl poměrně výraznou retrogenii, jeho mandibula byla krátká, $\mathrm{s}$ úhlem zapadlým v tukovém tělese, jeho vlasy světlejší a řidší, rovnější. Založení límce pod úhel mandibuly, jak ho má muž na fotografii, by u Kalisty nebylo možné bez hrubého násilí. Měl také úplně jiné ruce. Přestože jsme nalezli i jeden Kalistův snímek, který v koláži se studovanou fotografí působil velmi sugestivně, na základě početní převahy neslučitelných snímků se $\mathrm{k}$ této variantě nakonec nepřikláníme. Jeho př́tomnost v období, do kterého jsme fotografii datovali, není pravděpodobná ani z hlediska literárněhistorického, jak jsme ukázali výše.

Vlasy nás ale vedly k myšlence na Karla Konráda, jehož veřejně přístupná vojenská fotografie dávala určitou naději, ale po návštěvě depozitáře PNP v Litoměřicích, kde jsme prostudovali fotografie, ukazující zcela odlišný tvar lebky, čelisti i vlasové hranice, jsme ho také zavrhli.

Pomysleli jsme i na Antonína Matěje Píšu, ale jeho hypertelorismus se s fotografií vůbec neslučoval. Ani typický hranatý obličej a „netopýří uši“ Karla Teigeho jsme na fotografii neviděli. Stejně snadno jsme vyloučili i Ivana Sekaninu, jehož velký oválný obličej a výrazné světlé oči vůbec do podoby tohoto muže nezapadají. 
Posledním mužem, o jehož podobu jsme se velmi zajímali, byl Jan Pospíšil. Byl to právě on, kdo poukázky Wolkerovi zprostředkoval, a setkání na obědě by bylo zcela přirozené Pospíšil jistě neměl důvod obědvat jinde. Zde ale vyvstal problém: fotografii Jana Pospíšila nemá ani SOkA Prostějov, ani Muzeum a galerie v Prostějově, v jejichž pomoc jsme doufali. Oslovili jsme i veřejnost pomocí sociální sítě města Prostějova, ale bez úspěchu. Za pomoci ochotné archivářky jsme alespoň zjistili hlavní genealogické údaje, které nám pomohly nalézt prasynovce dr. Pospíšila. Jeho fotografii ale bohužel nevlastní a situaci ve zbytku rodiny komentoval slovy: „Vše ztraceno a zapomenuto.“ Je tedy možné, že třetí muž byl JUC. Jan Pospíšil, pozdější prostějovský advokát, ale vzhledem k absenci referenční fotografie tuto hypotézu nemůžeme ověrit.

Musíme připustit i možnost, že tento muž neměl s Wolkerem nic společného a že důvodem čekání byla nerušená př́prava fotografické techniky nebo přání nechat se fotografovat.

\section{Ověření identifikace}

Je subjektivní identifikace dostatečná? Odpovědět na tuto otázku je nesnadné až nemožné a objektivní kritéria k identifikaci osob podle fotografií se hledají těžko. K forenzním účelům odborníci zpravidla používají lidské hodnotitele s vysokým skóre v testu GFMT (Glasgow Face Matching Test). Jedná se o standardizovaný kognitivní test, sestavený za účelem zhodnocení schopností dané osoby rozlišit tváře neznámých osob. Ve své krátké verzi je sestavený ze čtyřiceti párů fotografií, které zachycují jednu a tutéž osobu nebo dvě různé osoby. Jak ale ukazuje recentní výzkum, skutečný výkon v praxi nekoreluje se skóre v tomto testu. ${ }^{55}$ Podobně problematický je i BTWFT (Before They Were Famous Test). Reálná praxe při rozlišování obličejů je tedy svízelná a univerzální řešení neexistuje.

Další možností jsou speciální aplikace - a tuto metodu jsme také využili. Aplikace Image Analysis Toolset (IAT) v módu Face comparison si počínala takto: Jiřího Wolkera vůči referenční fotografii identifikuje jako 67,81 \% shodu a značí zeleně na znamení souhlasu, přičemž jeho známé fotografie vzájemně skóruje mezi 50 a 100 \%, tedy srovnatelně. Kuriózní je, že o jedné osobě na skupinové fotografii si je aplikace zcela jista, že je to Jiří Wolker. Bohužel je to pán sedící za Wolkerem, který mu vůbec není podobný. U druhých dvou mužů jsou skóre ještě heterogennější, at' porovnáváme studovanou fotografii s referenční, nebo dvě známé. Aplikace sama o sobě tedy zjevně nemá pro porovnání fotografií velký prrínos, může pouze doplnit hodnocení předem vytipovaných a vizuálně porovnaných fotografií.

\section{Závěr}

Na základě systematického studia jsme došli k závěru, že jsme nalezli dosud neznámou fotografii Jiř́ho Wolkera a Karla Klause, která je cenná především z hlediska mapování Wolkerova života v Praze. Nabízí se zajímavé téma k zamyšlení - že si asi nikdo

55 Eilidh Noyes - Matthew Hill - Alice O'Toole, Face recognition ability does not predict person identification performance: using individual data in the interpretation of group results, Cogn Res Princ Implic. 3, 23 (2018); doi:10.1186/s41235-018-0117-4. 
z přítomných pánů neuvědomoval, jak neobvyklé a vzácné setkání to je. Že pozdější významný gynekolog obědvá se slavným básníkem.

\section{Poděkování}

Hlavní dík náleží Dr. Janu Šimkovi z Národního pedagogického muzea v Praze, který nám poskytl popisovanou fotografii.

Děkujeme i Mgr. Barboře Zelenkové z FF UP, která pomohla sestavit tvůrčí tým, pokrývající pole medicíny a její historie, antropologie a literární historie.

TEREZA KOPECKÁ - ZUZANA SCHIEROVÁ - RENATA FERKLOVÁ - ALEŠ MISǍ̆

\section{Nach der Arbeit hungrig, geniessen wir die eigenen Worte, oder der Kostgänger Jiří Wolker}

\section{ZUSAMMENFASSUNG}

Im Archiv des nationalen pädagogischen Museums J. A. Comenius und seiner Bibliothek (Národní pedagogické muzeum a knihovna J. A. Komenského) fand sich unter Fotografien aus studentischem Milieu der 1920er Jahre eine Aufnahme der Mensa des Studentenwohnheims, auf der wahrscheinlich Jiř́ Wolker zu sehen ist. In vorliegender Studie wird die Entstehungszeit der Aufnahme datiert, die Identität Jiř́ Wolkers überprüft, werden weitere Personen zu identifizieren versucht und wird der historische Kontext zu dem abgebildeten Geschehen vermittelt.

$\mathrm{Zu}$ diesem Zweck wurden anthropologische Methoden (subjektive und objektive) und eine große Menge historischer Quellen benutzt, vor allem publizierte Korrespondenz, mit deren Hilfe überprüft werden konnte, ob Jiř́ Wolker diese Mensa tatsächlich besucht hatte. Auch konnten einige Mythen über Wolker widerlegt und seine materiellen Verhältnisse richtiggestellt sowie seine Beziehungen zu Freunden erhellt werden, die sich in seinem Lebensstil in Prag spiegelten.

MUDr. Tereza Kopecká, Ph.D.

Ústav dějin lékařstvi a cizich jazyků 1. LF UK

tera.houbicka@gmail.com

Mgr. Zuzana Schierová

Ústav dějin lékařství a cizich jazyků 1. LF UK

Hrdličkovo muzeum člověka PřF UK

zuzana.schierova@natur.cuni.cz

PhDr. Renata Ferklová

Památnik národniho písemnictví, Praha

ferklova@pamatnik-np.cz

Mgr. Aleš Misar̆

Ústav historických véd, Filozofická fakulta Univerzity Pardubice

misarales@post.cz 


\section{Obrazová prríloha}

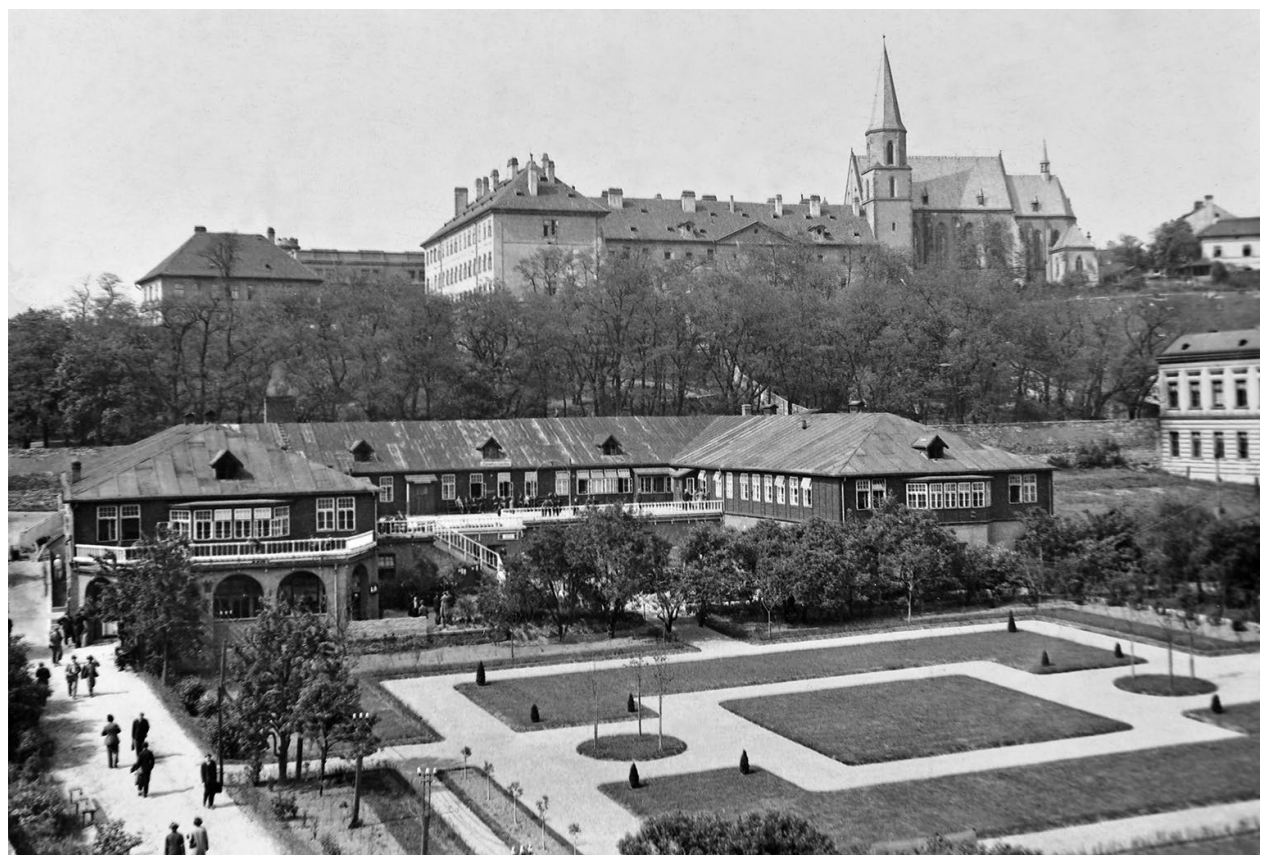

Obr. 1 Studentský domov v Praze na Albertově (1921-1928), celkový pohled na budovu (ze sbírky Národního pedagogického muzea a knihovny J. A. Komenského, sign. F 323/1; digitální kopie Petr Šolar)

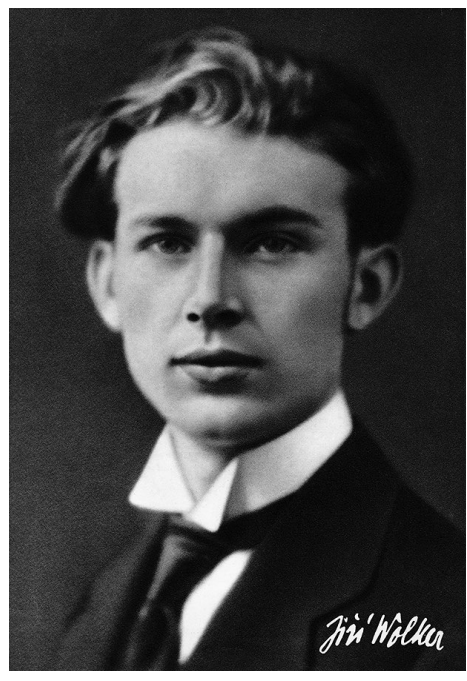

Obr. 2 Jiří Wolker (Fotoarchiv Literárního archivu Památníku národního písemnictví, sign. 630000020_020 88_001_00018a) 


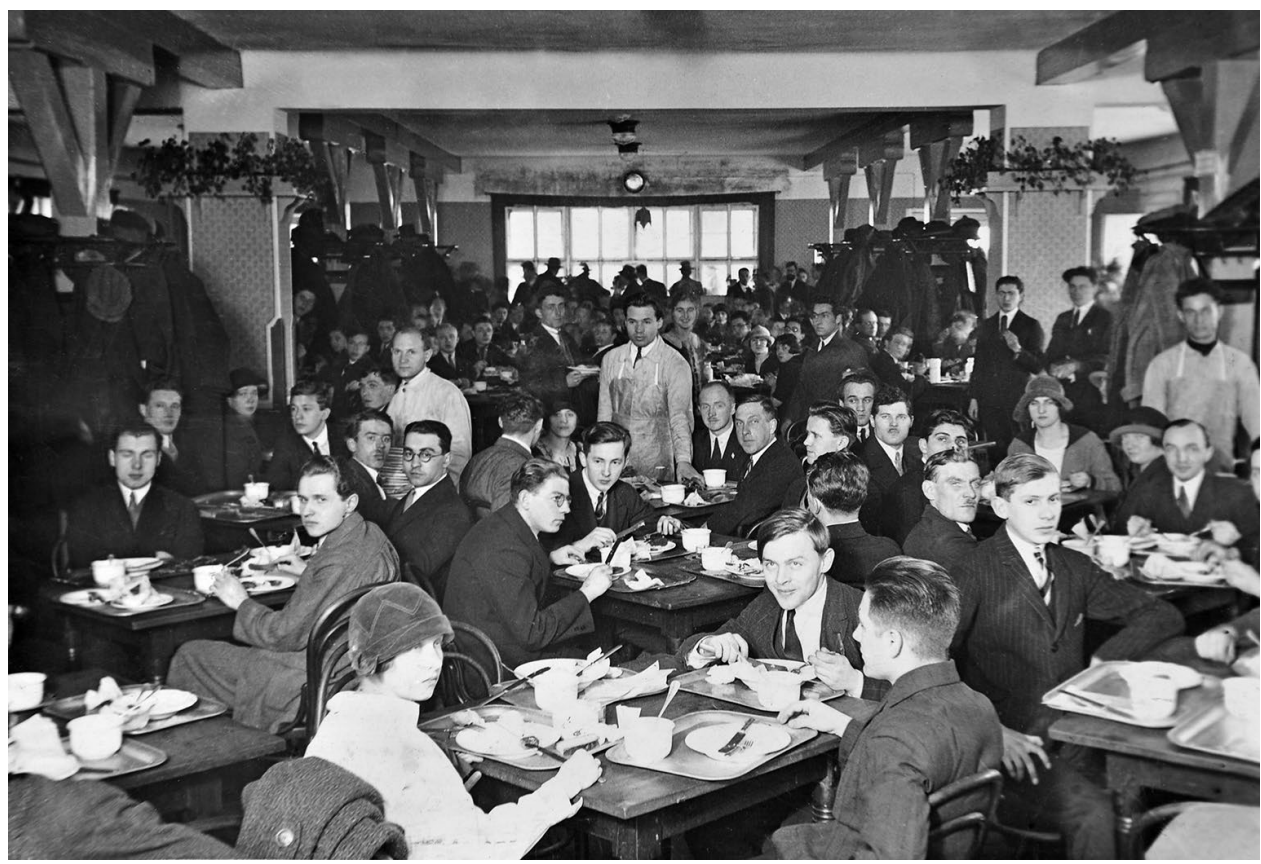

Obr. 3 Jídelna Studentského domova v Praze na Albertově (1921-1928), studie sleduje první stůl v levé řadě u stěny (ze sbírky Národního pedagogického muzea a knihovny J. A. Komenského, sign. F 323/6; digitální kopie Petr Šolar)

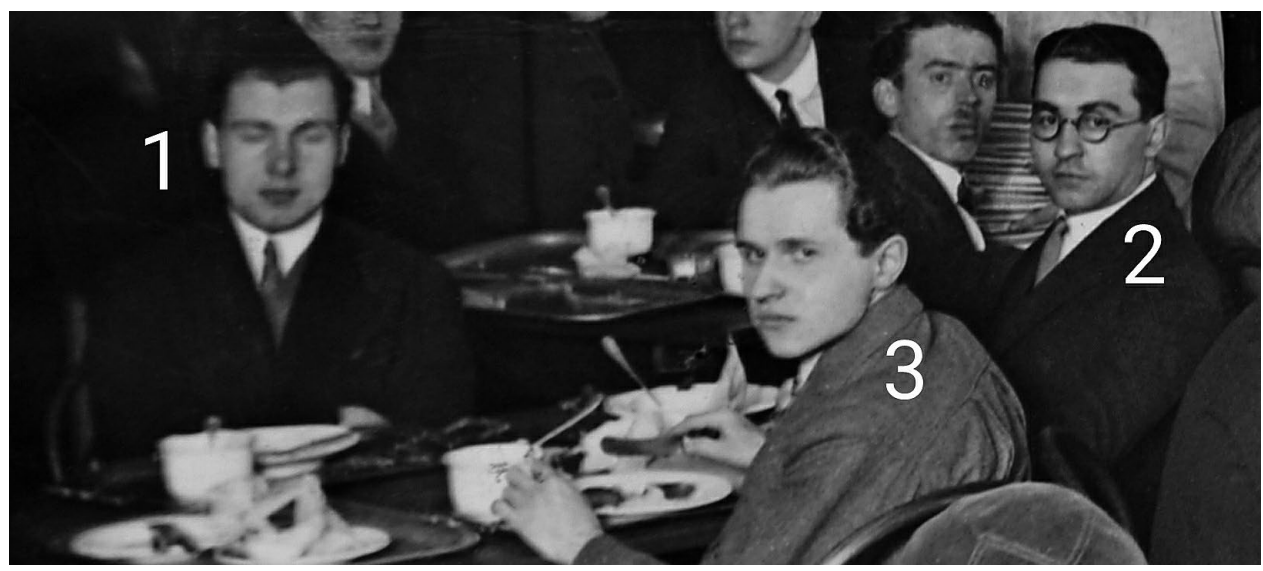

Obr. 4 Detail fotografie č. 3 - s identifikací osob: 1 - Jiří Wolker, 2 - Karel Klaus, 3 - neidentifikovaný muž. 


\section{Chronologie pobytů Jiřího Wolkera v Praze v letech 1921-1922}

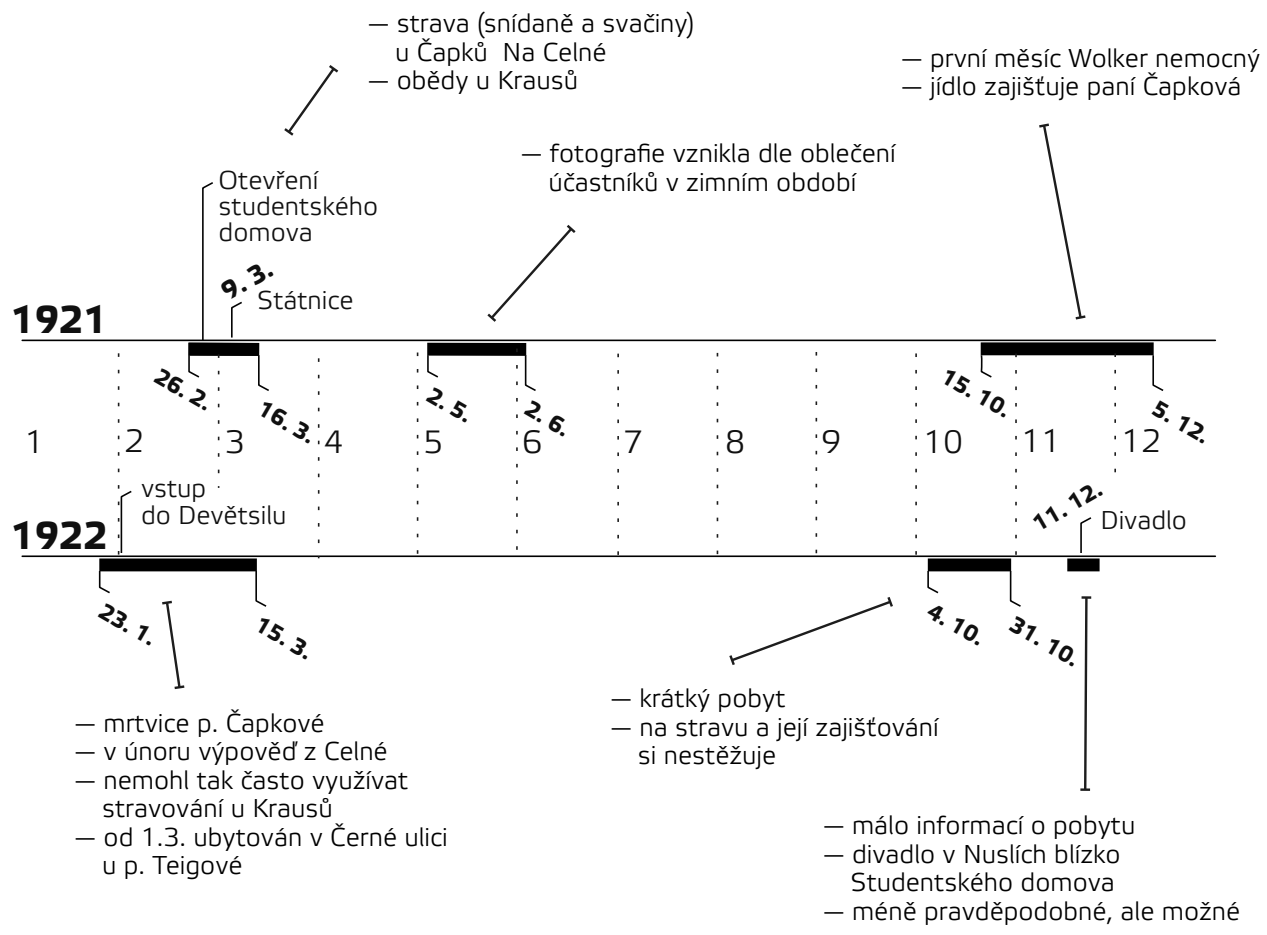

Obr. 5 Časová osa naznačující chronologii pobytů Jiř́ího Wolkera v Praze v letech 1921 1922 (zpracoval MgA. Martin Krupa) 